\title{
Implementation of Tokkatsu to Improve Face-to-Face Interaction Between Students
}

\author{
$1^{\text {st }}$ I Dewa Putu Eskasasnanda \\ Universitas Negeri Malang \\ Indonesia \\ dewa.putu.eskasasnanda.fis@um.ac.id
}

\begin{abstract}
The ability to interact and adapt to other human being is a crucial thing that humans must have. The development of information technology today has changed the form of interaction between humans. In universities it is known that the existence of modern communication media has made students no longer trained to interact face to face. Smartphone and social media is makes easy for students to interacting online. This make they prefer to do group assignments by online rather than meet in person. Through social media, students share, discuss material and complete reports on assignments together through online interaction. The lack of face to face interaction among students raises concerns because without the abilities to interacting offline, student will having dificulties to adapt with different person in the future. This paper will discuss implementation of Tokkatsu to build face-to-face interactions between university students. "Tokkatsu" is a common activity carried out in Japanese schools to build students' social emotional abilities. This article outlines what benefits students get from implementing Tokkatsu in their classrooms. By this reseach will be discussed, is Tokkatsu activity needs to be carried out further in other class.
\end{abstract}

Keywords: Tokkatsu, university students, face-to-face interactions

\section{INTRODUCTION}

Trying to continuously improve the quality of education is something that educators always strive to do. Educators strive to continually improve learning to be more beneficial to students. The main purpose of an educator is to provide important and valuable things for students.

Indonesian education today can be said focus on academic activities. Kasunagi in his research in Yogyakarta found that education in Indonesia places more emphasis on what the country wants. Educating according to Indonesian teachers is trying to give students what is desired by the national curriculum. The teacher feels as a source of learning and gives what is desired by the national curriculum. School learning is focused on national exam preparation [1].

Indonesian education that focuses on the national curriculum was also found by other researchers. Bjork (2005) found that in schools interactions between teachers rarely talk about learning practices. At school meetings, the ability to teach has never been evaluated, criticized for improvement or praise. The main basis for teacher evaluation in Indonesia is only how teachers fulfill the curriculum, how teachers carry out teaching schedules, carry out examinations, attend school meetings, ask students to take part in flag ceremonies, and other bureaucratic obligations. Teachers do not try to improve their teaching abilities because this is not much needed [2]

Related to the study of education in Indonesia it also appears that many Indonesian researchers focus on education in the academic section. Zulfikar (2009) for example, explains that successful teachers are those who are able to transfer knowledge successfully and effectively to students [3]. Meanwhile [4] argues that the purpose of Indonesian education is to shape the intellectual life of the nation.

Indonesian education which focuses on providing academic capabilities for students also occurs in universities. In university, the lecturers are busy focus on transferring academic abilities to students. Lecturers do not pay much attention to the social emotional development of students.

The advancement of information technology has changed the form of interaction between university students. Students of Social Sciences Education Study Program Malang State University for example, are known having difficulties in building a good group cooperation while in class. Social media has made easier for them interact online, therefore many interactions that were previously carried out with face to face are now carried out by online. Students explain many of them prefer to use online social media to do group assignments. Students discuss, plan and share group work through social media. This make students are untrain to do face to face interaction or a good group work when meet each other.

This paper will discuss the experience of carrying out "tokkatsu", a non-academic activity at university level. Tokkatsu is aims to provide an opportunity for student making intensive face-to-face interaction with classmates. The tokkatsu was 
carried out as a variation of the academic activities given to students. Students are asked to do tokkatsu in order to train them interacting face-to-face intensively. Tokkatsu providing a fun activities for student, hoping they will have better social relations with with each other.

\section{LITERATURE REVIEW}

\section{A. Tokkatsu Implementation at University}

The implementation of Tokkatsu at the University was inspired by the activities carried out by an elementary school learning expert from Japan named Ryo Suzuki. Ryo Suzuki argues that to make students learn well, a good classroom atmosphere is needed. Without a conducive classroom atmosphere, students will have difficulty implementing collaboration and learning will fail. One way to build a good classroom atmosphere is to carry out tokkatsu.

Tsuneyoshi et al (2016) explains that tokkatsu (tokubetsu katsudo) in Japanese terms is a special activity. Tokkatsu or special activities are carried out by giving non cognitive activities to students so that they experience character and social emotional development [5].

"Tokkatsu" is unique and only exists in education in Japan. According to Tsuneyoshi et al (2016), in the Japanese curriculum there are two types of learning activities for students. The first is learning activities that focus on students' cognitive abilities (mathematics, science, and literacy), and non-cognitive learning activities which are grouped as tokkatsu [5].

Tokkatsu as a non-academic activity, integrated in the Japanese curriculum aims that students gain social skills. Through tokkatsu, students experience their own collaborative learning in school. One form of tokkatsu activity that is popular in Japan is cleaning classes and preparing lunch. The school tries to integrate all non-cognitive activities in tokkatsu because it has various forms and is able to accommodate the different needs of the school.

Class cleaning activities by students are unique activities in Japan, this is different from other countries where cleaning classes is the task of janitors. Cleaning classes in Japan is not just a cleaning activity but as a learning activity at school. The teacher seriously facilitates students to carry out this activity, the teacher helps students conduct discussions, decision making, collaboration and collaboration in cleaning the class. Cleaning class activities as tokkatsu provides various educational functions for students, it is building interpersonal relationships between students and career education.

\section{B. Tokkatsu and Character Education in Indonesia}

Unlike the curriculum in Indonesia, the focus of the education curriculum in Japan is to provide whole education to students. According to Tsuneyosi et al (2016) Education according to Japanese philosophy, does not only train students' academic abilities through cognitive learning (subject matter) but also trains social emotional abilities through non cognitive activities. In the Japanese curriculum, educators not only want students to develop academically but also develop socially and emotionally. Lewis et al (2006), Shimahara and Sakai (2018) explain that education in Japan is oriented towards the formation of individuals as a whole, supporting a balanced development between thought, body and soul [6], [7].

Kusanagi (2013) explains that Japanese teachers consider that the overall development of students is the most important goal of education. Teachers in Japan not only want to be good teachers but also become role models in students' morals and spirituality. Every aspect of student life is the teacher's attention. The teacher seeks to build good relationships with students and conversations between teachers are filled with talk about student problems and discipline [1].

Tsuneyoshi (2004) says that the basis for doing tokkatsu in Japanese schools is the philosophy of relaxed education which began in Japan in 2002. The 2002 Japanese curriculum tried to reduce pressure on students by providing more flexibility to develop. This minimal pressure education is called education for "yutori" (relaxed education) or education that will allow children "room to grow" [8].

Education for yutori is the opposite of high pressure education which emphasizes testing. Education that emphasizes testing is known to cause various problems for students. Some of these things include making some students feel depressed if they are unable to follow, lose confidence and engage in bad behavior such as violence, bullying, and skipping school. Yutori education is concerned with the emergence of student initiative, thinking ability and pleasure in learning. Yutori's education is aimed at providing a passion for life, training students to do selfdiscovery, self-learning, and hands-on experience.

The study found that although tokkatsu was not a cognitive activity, tokkatsu was able to support students' social and academic development. Komoto (2015) found that tokkatsu was included in the school curriculum and was designed to shape interpersonal skills, shape student character and their emotional maturity. Tokkatsu is able to build good social relations between students, the school community and collegial relations between teachers. It was evident that after three years of practicing tokkatsu at Kuwabara school, Tokkatsu was able to make school truant numbers drop to one third and student academic performance increased. Tokkatsu is able to bring students closer to each other so that their academic performance increases. The Kuwabara Junior High School which was originally the second worst school in the region, became ranked first in the next three years with student exam scores exceeding national and local average scores [9].

Related to efforts to improve students 'social emotional abilities, Kasunagi (2019) explained that currently there is an increasing interest in Indonesian educators to train students' social and emotional skills. Indonesian educators not only want 
education to be able to train only cognitive aspects but also students' social emotional abilities. The form of social emotional education in Indonesia is known as "character education". Character education is considered important by the government because it is motivated by rapid economic growth and national security needs. The Indonesian government feels that rapid economic growth in Indonesia has led to drastic changes in people's lives, changes in lifestyle and moral degradation of young people[10] .

Character education in Indonesia according to Kusanagi is a combination of two subjects in the curriculum, namely religious and citizenship education. Teachers are asked to include these two elements of education in each lesson they teach. Although it is considered important, the implementation of character education in Indonesia does not yet have a clear picture. Character education in Indonesia is implicit in the curriculum and many Indonesian teachers include it in the RPP (learning planning sheet) but sometimes are unable to implement it due to lack of knowledge and time.

To overcome the teacher's lack of knowledge about forms of character education, several schools in Bandung, West Java were interested in carrying out tokkatsu activities. According to Kusanagi (2019) several schools in Bandung are trying to carry out Tokkatsu activities like in Japan, namely lunch preparation activities. Through this tokkatsu the teachers hope to equip students not only with academic abilities but also social and emotional skills to become good members in the community [10, p. 20].

\section{METHOD}

The purpose of this paper is to explain the impressions of university student about the implementation of Tokkatsu in their class. Information from the students was explored through indepth interviews to 40 students of the Malang State University social studies program class of 2016 offering A in the course of Cultural Anthropology. Information was extracted through interviews conducted at the end of the semester.

In this study the authors are act in dual roles, as lecturers of subjects and researchers. The author teaches the course, asking students to interact with each other by carrying out tokkatsu and researching it. When students carry out Tokkatsu, researchers observe behavior and at the end of the semester researchers conduct interviews with them. This study focuses on finding out the impressions of students on tokkatsu activities that they do in class. Whether Tokkatsu activities have the benefit of improving interaction with fellow students and whether this activity needs to be carried out in the next semester.

\section{RESUlTS AND DISCUSSION}

\section{A. Tokkatsu Implementation in University Lectures}

Tokkatsu or non-academic activities are carried out in the course of Cultural Anthropology. In the course, when students feel bored with academic lessons and material discussions, students are asked to do tokkatsu in groups of 4 people. Group members are randomly picked and selected quickly through a pat game. In order to make students closer to all friends, every tokkatsu activity is carried out in different groups every week

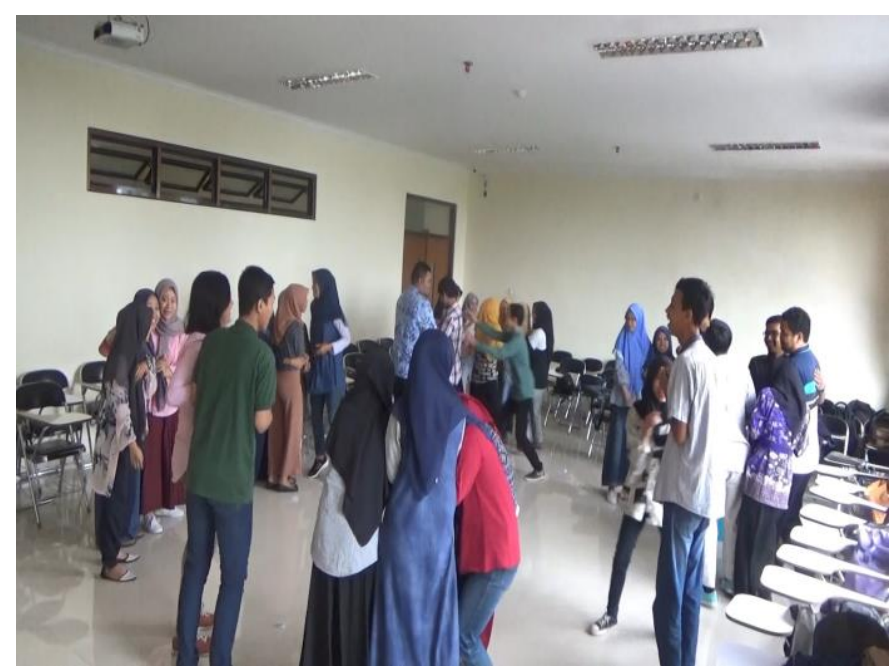

Fig. 1. A pat game to create a working group

When students are formed in groups, students are asked to compete with other groups in challenging activities. The form of this challenging group activity was inspired by the activities carried out by Ryo Suzuki, an learning expert from Japan in elementary schools in Malang. Each group activity requires students to coordinate face-to-face with friends and conduct group collaboration. To be more clear about the forms of group work activities carried out in the class can be seen in a few pictures below.

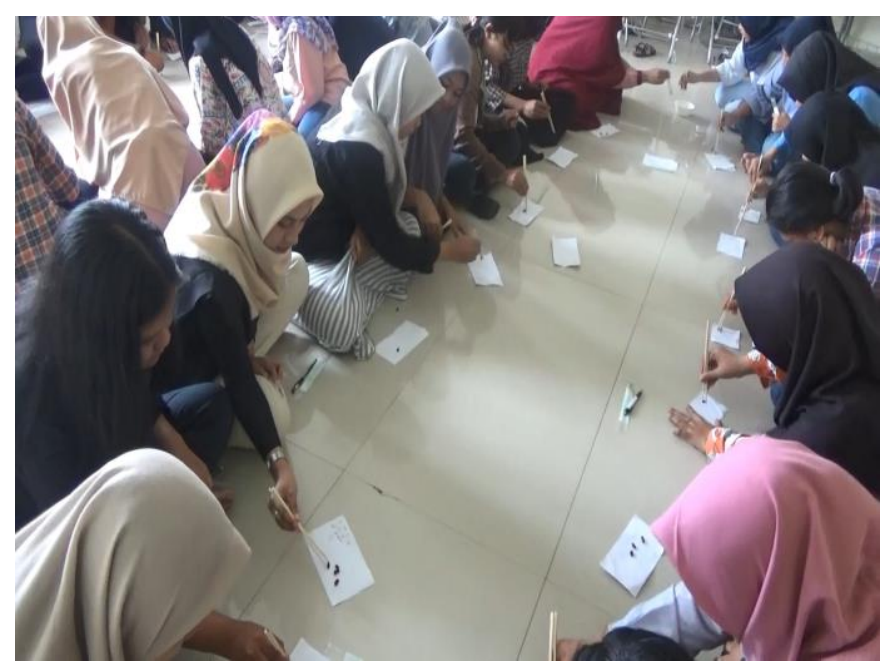

Fig. 2. Tokkatsu, shifting a beans with chopsticks 


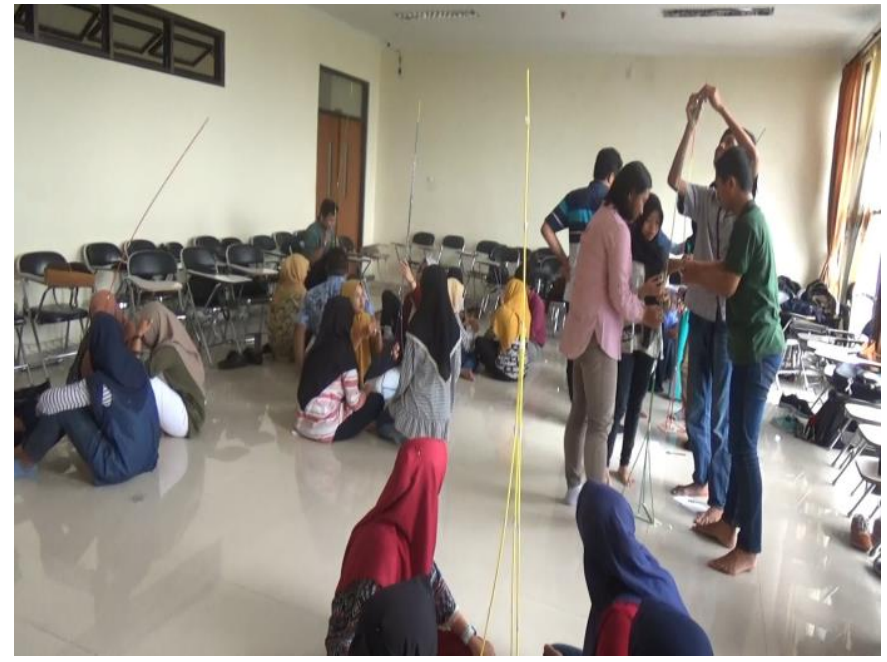

Fig. 3. Tokkatsu, building a straw tower

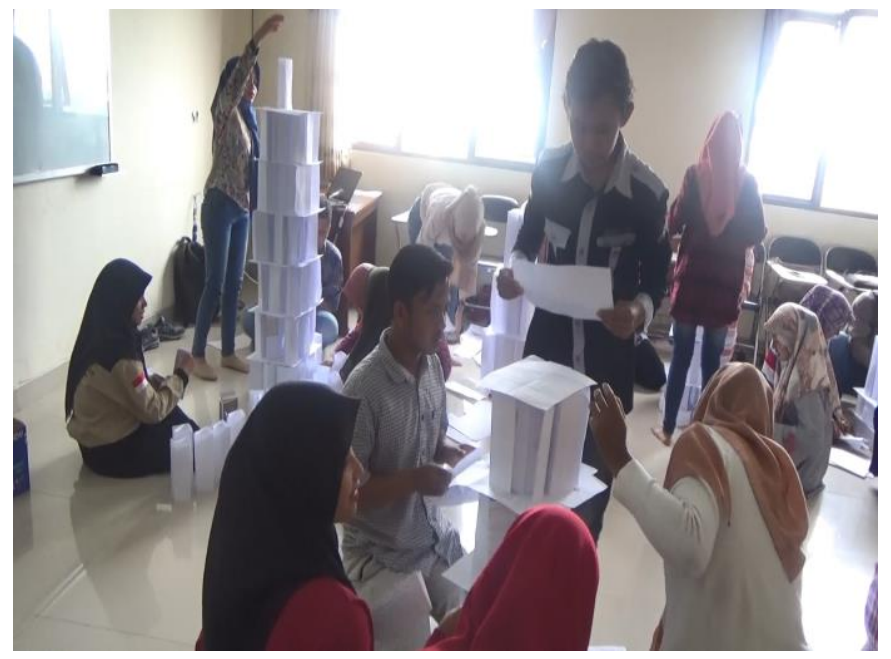

Fig. 4. Tokkatsu, makes a paper tower

\section{B. Benefits of Tokkatsu for University Student}

Based on the results of observations and interviews with 40 students who conduct tokkatsu, it was found that all students had a positive comment on the implementation of tokkatsu in the classroom. All students admitted that they really enjoyed this activity and said that this activity was positive because it provided a new atmosphere in the classroom. The students explain that tokkatsu could eliminate a bit of boredom in attending classes. For the detail about the benefits students felt about tokkatsu will be explain in several sections bellow:

\section{1) Give a New Atmosphere to the Class}

Based on the results of the interview, it was found that the students felt that Tokkatsu provided a new atmosphere in college. Students felt the lecture atmosphere they had been participating in seemed monotonous because it focused only on academics. Lecturers always teach with lectures, material explanations, presentations, student discussions and group assignments. This makes students feel tired because they must always study learning material and theories. Plus they are required to do independent academic assignments and group assignments every week. Tokkatsu makes students feel happy because they can make them have fun with their classmates. According to students, tokkatsu makes students carry out balanced activities, not only physical exercise but also thinking without heavy academic pressure. Tokkatsu is a fun activity and can be used to relieve stress, forgetting for a moment the pressing academic assignments.

Students feel bored with day-to-day lectures because they only learn academic things. Studying scientific material is important because it expands knowledge. However, studying science every day can make students feel bored. Carrying out tokkatsu made students feel more relaxed even though the mind remained focused on the class.

\section{2) Practicing Interaction Skills and Creating Closer Relationships Between Students}

Tokkatsu is done by students in groups. Through interviews it is known that when implementing Tokkatsu, students learn how to cooperate and understand how important collaboration is. Two students explained that in group work, if one person dominates the discussion, then there is a high probability that the group will fail. Group work will be difficult to do if all members have not agreed on something. For group work to run smoothly, all group members must express all ideas and agree on the best ideas to be implemented. If an agreement has been reached then group collaboration will be easier because all group members know what they have to do and will work wholeheartedly. Group work will run smoothly, pleasantly and in no hurry because success and failure have become the responsibility of all members.

The main purpose of tokkatsu is to make face-to-face interaction between students in the class more intensive. At each tokkatsu, students are grouped with different members who are chosen randomly. Playing with different team members turns out to be able to make students learn and adapt to the various characteristics of their friends. Four students said that through tokkatsu, they became more acquainted with their classmates.

The students said that although they had known each other for 2 years, there were no class activities that could make them interact intensively like Tokkatsu. In lectures, students usually prefer to work in groups with known friends. In tokkatsu, team 
lecture because they don't have the experience of having fun with friends. The students claimed to prefer attending college rather than skipping class because attending class was more fun. Morning courses are no longer an unpleasant thing. Students are not reluctant to get up, feel excited, want to immediately get out of bed and go to college because college is not something heavy and boring but entertaining and enjoyable.

\section{4) Giving Practical Ability to Students}

An unexpected benefit from the implementation of tokkatsu is the practical benefits obtained by pedagogical students. Two students admitted that tokkatsu gave them practical abilities on how to organize classes. As junior high school teacher candidates, the students claimed not to have enough knowledge and a clear picture of how to teach well.

According to students, good teachers are those who are fun and can manage classes. The students realize that if the teacher only gives academic lessons it will definitely make students tired. When students are tired and bored, teachers must provide non-cognition activities that can relieve their physical and mental fatigue. Through Tokkatsu, students can feel relaxed but stay focused in class. This experience makes students have a little picture of what can be done when they have to teach at school and students experience boredom in learning. The more tokkatsu they experience in the class, the more solutions students have to overcome students' lack of enthusiasm.

In addition to practical abilities to become a teacher, tokkatsu also provides practical abilities that can be used in families and communities. Doing tokkatsu games in class, giving students a happy time with their peers. This happy feeling then wants to be transmitted to people around the students. Some students took the initiative to practice tokkatsu with relatives or children around their homes. This turned out to be positive, when tokkatsu was practiced, siblings and children who were previously sad and bored became happy. This experience makes students feel meaningful because they can provide benefits to the community. Through tokkatsu they are able to show others that simple equipment such as used paper, straws and others can be transformed into fun game equipment.

Besides being beneficial to family members and the community, two students claimed to practice tokkatsu in mosques and schools. Tokkatsu turned out to make students happy and more enthusiastic to attend scout activities and study the Koran. The experience of implementing tokkatsu makes students feel more confident, they feel they have the ability to solve a social problem that occurs in the surrounding social environment.

Based on research, it is known that the implementation of tokkatsu in class provides several benefits for university students. The first benefit of tokkatsu is provides a different atmosphere for students. Students explain tokkatsu can make the classroom atmosphere feel different. The class feels fun, so it admitted that they love it, and feel disappointed when miss one 
can reduce boredom in attending classes. Conventional university lectures that only focus on academic activities such as speech, discussions and assignments often make students bored and stressed. Conducting tokkatsu in class provides a different atmosphere, a pleasant learning atmosphere where student can discuss, interact and solve the problem they faced and then study in class.

The second benefit of tokkatsu is become media to conduct more intensive face-to-face interactions among student. In tokkatsu, student working in groups which consist of different member at each meeting. This experience makes students interact and get acquainted to each other, they learn how to make a groupwork effectively, and adapt with many human characters. This experience surely will be beneficial for student in the future because in society they must adapt with a various kinds of people.

Grouping and interacting with unfamiliar friends, found out also can make students throw away their prejudice with each other. Through tokkatsu, a high academic students get to know and realized that a low academic students who previously they considered lazy and unmotivated, found out also energetic, having motivation and responsibility in completing a task. In fact, a low academic student often have a brilliant idea and agility in completing a task. This experience makes high academic students realize that there are no students in class who are lazy and unmotivated to learn. All students have their own passion, strengths and weaknesses.

The third benefit of tokkatsu for university students is giving a practical abilities for their life. As a student teacher, it is important for student having a practical abilities which can be use in managing a classroom. Tokkatsu can bring happiness, creating a vibrant and lively atmosphere in the classroom. This experience will be beneficial for student when they becoming a teacher in the future. Tokkatsu can be use to make their student happy and motivated to learn in class.

\section{CONCLUSION}

Although the implementation of tokkatsu can create a new atmosphere in the classroom and is fun for students, it is not wise to apply this non-cognition too often in class. The thing to think about is the right amount to implement tokkatsu in class so that it can provide students with the fun of learning without disturbing them.

The second thing I learned from the implementation of tokkatsu was that although students were tired of learning, their enthusiasm and desire to learn would arise if they were asked to implement tokkatsu. This shows that the boredom of learning is not an obstacle for humans to do other thinking activities. Tokkatsu is loved by students because it makes them think about problems that exist and are close to students. This is of course can be integrated in cognitive learning. This research show that preferred form of learning by student is discuss things that are close, useful for them. If learning is considered important and provides practical abilities, students will be motivated to learn and joyfully follow it.

\section{REFERENCES}

[1] K. N. Kusanagi, "The Bureaucratising of Lesson Study: A Javanese Case.," Math. Teach. Educ. Dev., vol. 16, no. 1, p. n1, 2014.

[2] C. Bjork, Indonesian education: Teachers, schools, and central bureaucracy. Routledge, 2005.

[3] T. Zulfikar, "The making of Indonesian education: An overview on empowering Indonesian teachers," J. Indones. Soc. Sci. Humanit., vol. 2, pp. 13-39, 2010.

[4] A. Sukasni and H. Efendy, "The problematic of education system in Indonesia and reform agenda," Int. J. Educ., vol. 9, no. 3, pp. 183-199, 2017.

[5] R. Tsuneyoshi, K. Kusanagi, and F. Takahashi, "Cleaning as Part of TOKKATSU: School Cleaning Japanese Style," Cent. Excell. Sch. Educ. Grad. Sch. Educ. Univ. Tokyo Work. Pap. Ser. 21st Century Int. Educ. Models Proj., no. 6, 2016.

[6] C. Lewis, R. Perry, J. Hurd, and M. P. O’Connell, "Lesson study comes of age in North America," Phi Delta Kappan, vol. 88, no. 4, pp. 273-281, 2006.

[7] N. K. Shimahara and A. Sakai, Learning to teach in two cultures: Japan and the United States. Routledge, 2018.

[8] R. Tsuneyoshi, "The new Japanese educational reforms and the achievement 'crisis' debate," Educ. Policy, vol. 18, no. 2, pp. 364-394, 2004.

[9] A. Komoto, "Collaborative Efforts to Build Interpersonal Skills and Emotional Maturity Across School Levels Through Tokkatsu," PhD Thesis, The University of Tokyo, 2015.

[10] K. Kusanagi, "Character Education in Indonesia and Growing Interest in Tokkatsu," PhD Thesis, The University of Tokyo, 2019. 